\title{
A CONVERSATION AFTER DINNER
}

Eyes afire in the lamplight,

Shining softly in the night,

Such eyes! and cheeks, and lips aglow,

More beautiful than words can show.

I sat, I heard, and oh! her voice!

A sound that made my heart rejoice!

It tickled me to brim with glee:

I smiled, listened giddily.

Her hands fell softly in her lap-

They rose and fell as soft as snow-

I watched them closely, deeply rapt,

And ached to catch them in my own.

Her tilted head, her moving lips, They called out to my fingertips, And yet my mind warned not to touch, Reproached me not to dare so much, For fear I might the least offend And in my haste, lose a friend.

Was it wine that whirled my head, And made my vision start to dim?

Or was it her liqueur instead, Her soft intoxicating grin? 
I cannot say, I do not know!

The evening rushed away so fast!

And I-intoxicated so-

Could only hope it weren't the last.

Sweet trembling and unusual fright!

I cannot match her high perfection,

And that is why I fear her sight,

And yet I crave her deep affection. 